\title{
New particle formation in the Front Range of the Colorado Rocky Mountains
}

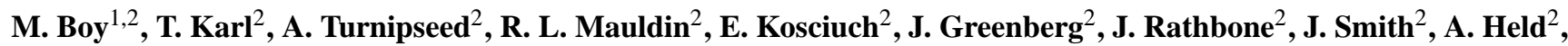 \\ K. Barsanti ${ }^{2}$, B. Wehner ${ }^{3}$, S. Bauer ${ }^{3}$, A. Wiedensohler ${ }^{3}$, B. Bonn ${ }^{4}$, M. Kulmala ${ }^{1}$, and A. Guenther ${ }^{2}$ \\ ${ }^{1}$ Department of Physical Sciences, P.O. Box 64, 00014 Helsinki, Finland \\ ${ }^{2}$ ACD, NCAR, P.O. Box 3000, 80305 Boulder, Colorado, USA \\ ${ }^{3}$ Leibniz Institute for Tropospheric Research, Permoserstrasse 15, 04318 Leipzig, Germany \\ ${ }^{4}$ Department of Plant Physiology, Estonian University of Life Sciences, Kreutzwaldi 64, 51014 Tartu, Estonia
}

Received: 2 October 2007 - Published in Atmos. Chem. Phys. Discuss.: 5 November 2007

Revised: 12 February 2008 - Accepted: 26 February 2008 - Published: 17 March 2008

\begin{abstract}
New particle formation is of interest because of its influence on the properties of aerosol population, and due to the possible contribution of newly formed particles to cloud condensation nuclei. Currently no conclusive evidence exists as to the mechanism or mechanisms of nucleation and subsequent particle growth. However, nucleation rates exhibit a clear dependence on ambient sulphuric acid concentrations and particle growth is often attributed to the condensation of organic vapours. A detailed study of new particle formation in the Front Range of the Colorado Rocky Mountains is presented here. Gas and particle measurement data for 32 days was analyzed to identify event days, possible event days, and non-event days. A detailed analysis of nucleation and growth is provided for four days on which new particle formation was clearly observed. Evidence for the role of sesquiterpenes in new particle formation is presented.
\end{abstract}

\section{Introduction}

New particle formation (NPF) has been observed at many locations on the Earth's surface, in varying types of environments (Kulmala et al., 2004). Once newly formed particles have grown beyond $50 \mathrm{~nm}$ in diameter they may act as cloud condensation nuclei, thereby affecting cloud properties. Observations of NPF events have revealed a relationship between nucleation rates and ambient sulphuric acid concentrations, with either a linear $\left(J=A^{*}\left[\mathrm{H}_{2} \mathrm{SO}_{4}\right]\right)$ or squared $\left(J=K^{*}\left[\mathrm{H}_{2} \mathrm{SO}_{4}\right]^{2}\right)$ dependence on concentration (Kulmala et al., 2006; Sihto et al., 2006; Riipinen et al. 2007). An activation mechanism has been evoked to explain the linear de-

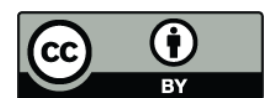

Correspondence to: $\mathrm{M}$. Boy

(michael.boy@helsinki.fi) pendency, and a kinetic mechanism the squared dependency, both of which involve sulphuric acid molecules forming stable clusters (Kulmala et al., 2006). Other theories have been proposed, such as a recent one involving biogenic organic molecules, in which ozonolysis products of sesquiterpenes react to produce low-volatility organic sulfates or secondary ozonides (Bonn et al., 2007). The formation of the lowvolatility compounds is facilitated by sulphuric acid, which may lead to the observed relationship between nucleation rates and sulphuric acid concentrations. Currently no conclusive observations have been made as to which of the proposed processes (or combination of processes) leads to NPF.

Here we present a detailed study on NPF in the Front Range of the Colorado Rocky Mountains. The influence of different parameters is discussed for four categories of NPF event days, from clear event days to non-event days. NPF was clearly observed on twelve of thirty-two days. The nucleation and growth mechanisms responsible for the formation of detectable particles on four NPF days are discussed in detail. Also presented is some of the first evidence of the role of organic compounds in the early stages of new particle growth, through the formation of larger organic molecules such as oligomers.

\section{Experimental}

\subsection{Mountain Research Station}

The field study was conducted at the University of Colorado Mountain Research Station (http://www.colorado.edu/mrs/) in June and July 2006 to study occurrence and mechanism of new particle formation at an elevated forest environment. This site is located approximately $25 \mathrm{~km}$ west of Boulder, Colorado on the leeward side of the Rocky Mountains at

Published by Copernicus Publications on behalf of the European Geosciences Union. 


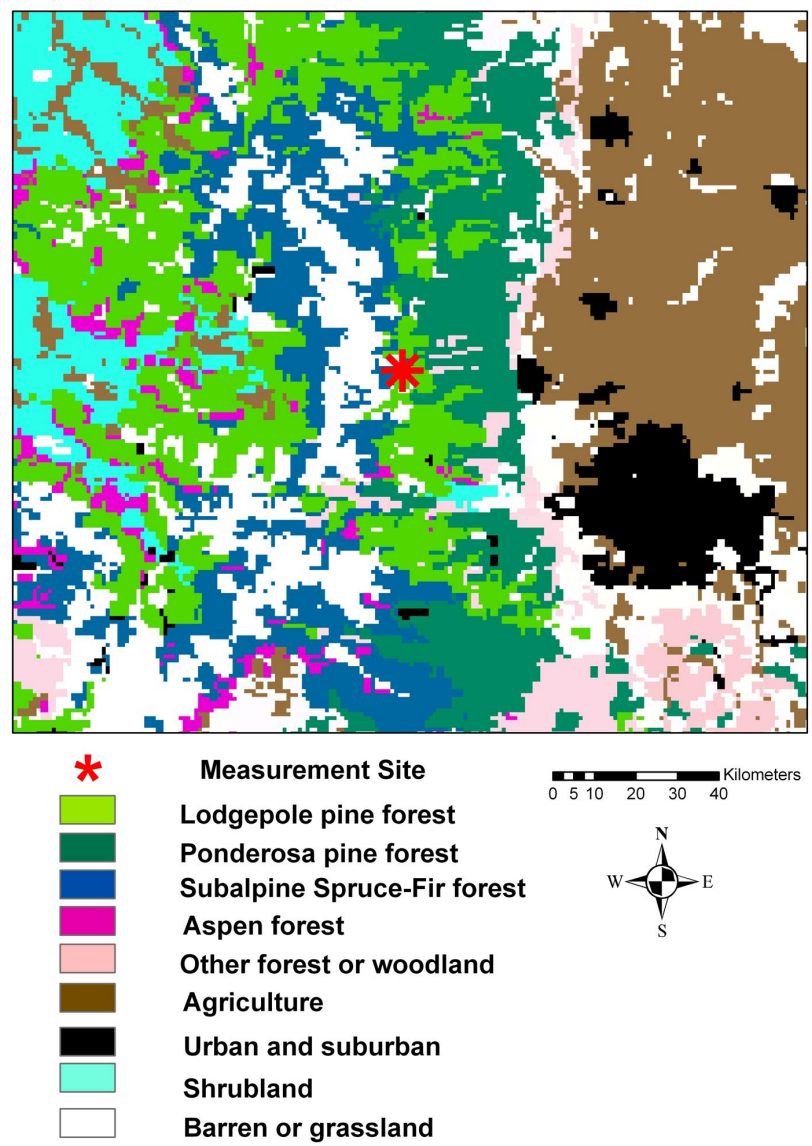

Fig. 1. Map of the dominant landcover within about $100 \mathrm{~km}$ of the measurement site.

an elevation of $2900 \mathrm{~m}$. The continental divide (elevation of $\sim 3600 \mathrm{~m}$ ) lies $\sim 9 \mathrm{~km}$ west of the site. The meteorology at this site has been described on numerous occasions (e.g., Brazel and Brazel, 1983; Parish et al., 1990; Turnipseed et al., 2002) and often exhibits a typical valley-mountain flow in the summertime. In the absence of strong synoptic forcing, winds are typically westerly at night (downslope drainage) bringing relatively clean air from the continental divide; whereas daytime heating creates easterly (upslope) flow, bringing air from the Denver-Boulder metro area. All gas and particle measurements were made within a forest clearing on the north side of the site to minimize influences from local pollution sources (e.g., campfires, vehicular traffic). The immediate surrounding forest consists mainly of Lodgepole pine (Pinus contorta) with a canopy height of $\sim 10 \mathrm{~m}$ (see Fig. 1). Further to the east and south is riparian area that is dominated by aspen (Populus tremuloides).

\subsection{Twin Differential Mobility Particle Sizer and Thermod-} enuder (TDMPS-TD)

Aerosol number size distributions in the size range from 3 to $800 \mathrm{~nm}$ were measured under dry conditions using the Twin Differential Mobility Particle Sizer, TDMPS (Birmili et al., 1999). The TDMPS consists of two Hauke type Differential Mobility Analyzers (DMAs) and two Condensation Particle Counters (CPCs, Model 3010 and UCPC Model 3025, TSI Inc. St. Paul, MN, USA). Additionally, a thermodenuder, TD (Wehner et al., 2002) was placed upstream of the mobility size spectrometer. Particle size distributions were measured with and without thermodesorption in an alternating manner. During their passage through the TD, particles were heated to $300^{\circ} \mathrm{C}$, resulting in the evaporation of volatile constituents. Semi- and non-volatile constituents, such as soot or long-chain hydrocarbons, likely remain in the particle phase at $300^{\circ} \mathrm{C}$ and were detected as "non-volatile" cores. Thus the number size distribution after the TD represents the size distribution of non-volatile particles or particle cores. The inlet used was a commercially available low-flow PM10 inlet (Thermo Anderson, Smyrna, GA, USA).

\subsection{Chemical Ionization Mass Spectrometer (CIMS)}

The Chemical Ionization Mass Spectrometer measured sulphuric acid nearly continuously through the campaign. The instrument consists of a mass spectrometer coupled to a lowpressure flow tube and is very similar to that described in Leibrock and Huey (2000). The mass spectrometer is housed in a vacuum chamber with two sections, each of which evacuated with a $2501 \mathrm{~s}^{-1}$ hybrid turbopump. The first section contains ion optics that guide the ion beam originating from the flow tube into the second section containing the quadrupole mass filter and an ion detector. The flow tube is constructed from stainless steel and is $10.2 \mathrm{~cm}$ long with an inner diameter of $3.5 \mathrm{~cm}$. Air is continuously sampled into the flow tube at a flow rate of ca. 2.0 SLPM through a $0.64 \mathrm{~mm}$ diameter, conically shaped orifice. A flow rate of 4.0 SLPM nitrogen containing a few ppmv of $\mathrm{SF}_{6}$ (sulphur hexafluoride) is also added to the flow tube via a ${ }^{210} \mathrm{Po}$ ion source. $\mathrm{NH}_{3}$ at $5 \mathrm{sccm}$ is also added to the ion source to suppress the $\mathrm{HNO}_{3}$ background (Huey et al., 1998). The flow tube is maintained at a pressure of 12 torr by an oil sealed rotary vane pump. Ions produced in the ion source mix with the sampled air to allow reaction along the length of the flow tube. A small portion of this flow $(\sim 10 \mathrm{sccm})$ is sampled through an orifice into the mass spectrometer. The effective reaction time in the CIMS in this configuration is $\sim 20 \mathrm{~ms}$ and is primarily determined by the length of the flow tube and the gas flow conditions. The temperature of the flow tube was not controlled and was approximately $283 \mathrm{~K}$. 


\subsection{Proton Transfer Reaction Mass Spectrometer (PTR- MS)}

The Proton Transfer Reaction Mass Spectrometer (PTR-MS) has been described in detail elsewhere (de Gouw et al., 2003; Hansel et al., 1998; Lindinger et al., 2001; Lindinger et al., 1998). The instrument measured several organic vapours including mono- and sesquiterpenes continuously with a break of seven days. The sensitivity of the PTR-MS during this field study was typically on the order of $70 \mathrm{~Hz} / \mathrm{ppbv}$ (counts per second per ppbv) for acetone and $50 \mathrm{~Hz} / \mathrm{ppbv}$ for methanol at 2.0 mbar buffer gas pressure with a reaction time of $110 \mu \mathrm{s}$ and $8-10 \mathrm{MHzH}_{3} \mathrm{O}^{+}$ions. The detection limit (DL) for compounds investigated in this work was inferred from a signal to noise ratio $(\mathrm{S} / \mathrm{N})$ of 2 according to $\mathrm{DL}=$ $2 \times$ SDblank/sensitivity, with SDblank being the standard deviation of background count rates. For a $5 \mathrm{~s}(2 \mathrm{~s})$ integration time this resulted in theoretical detection limits around $\sim 20 \mathrm{pptv}(\sim 58 \mathrm{pptv})$. We used a gravimetrically prepared multi component VOC standard to calibrate the PTR-MS instrument for methanol, acetonitrile, acetone, acetaldehyde, benzene, toluene, isoprene, MVK (methyl vinyl ketone) and camphene with an estimated uncertainty of $+/-15 \%$. Sesquiterpene concentrations monitored on $\mathrm{m} / \mathrm{z} 205$ were averaged for $2 \mathrm{~h}$ and calibrated based on the $\beta$-caryophyllene fragmentation pattern obtained from a pure standard.

\subsection{Trace gases}

A suite of trace gases were continuously measured throughout the campaign. Air was sampled at a height of $6 \mathrm{~m}$ through a Teflon particulate filter and then brought to a series of gas analyzers through $\sim 7 \mathrm{~m}$ of PFA tubing. Ozone was measured by UV-absorbance (Thermo Environmental, Model 49 ), and $\mathrm{SO}_{2}$ was measured by pulsed laser fluorescence (Thermo Environmental, Model 43C-TLE). NO was measured using the $\mathrm{NO} / \mathrm{O}_{3}$ chemiluminescence method (Ecophysics, Model $88 \mathrm{Y}$ ). Subsequently, the sum of $\mathrm{NO}_{\mathrm{y}}$ species $\left(\mathrm{NO}_{\mathrm{y}}=\mathrm{NO}+\mathrm{NO}_{2}+\right.$ peroxy nitrates + alkyl nitrates $)$ was measured by passing the sample gas through a heated $\left(325^{\circ} \mathrm{C}\right)$ molybdenum converter, which reduces these species to and detects these species as NO. Components of $\mathrm{NO}_{\mathrm{y}}$ that were either reactive (e.g., $\mathrm{NO}_{3}$ ) or difficult to pass through the inlet (e.g., $\mathrm{HNO}_{3}$ ) likely were not sampled quantitatively. However, these components are often $<15 \%$ of the total $\mathrm{NO}_{\mathrm{y}}$ and their exclusion does not create a large error in the measurements. The detection limits for the $\mathrm{SO}_{2}$ and $\mathrm{NO}$ analyzers were in accordance to the manufacturers' specifications ( $\sim 40$ pptv for both, 2 min. avg.) and the estimated accuracy was $\sim \pm 20 \%$. The detection limit of the ozone analyzer was $\sim 3$ ppbv and had an estimated uncertainty (accuracy) of $\pm 7 \%$ from comparison with other analyzers. $\mathrm{SO}_{2}$ was automatically calibrated every $4 \mathrm{~h}$ by addition of either a zero gas or a known concentration of $\mathrm{SO}_{2}$. The gain coefficient varied less than $5 \%$ over the course of the experiment. The
$\mathrm{NO} / \mathrm{NO}_{\mathrm{y}}$ system, calibrated periodically throughout the campaign, was found to vary less than $12 \%$. Output from the gas analyzers was logged every $10 \mathrm{~s}$ and then averaged over 2 or 5 min.

\subsection{Meteorology and climate variables}

Basic meteorological measurements were made at the measurement site with a small met station, located at a height of $2.5 \mathrm{~m}$. Environmental variables such as wind speed and direction, which are impacted by the surrounding canopy, were taken from nearby sites. The primary source for supplemental meteorological data was the Niwot Ridge Ameriflux site (http://spot.colorado.edu/ monsonr/ Ameriflux.html) that lies within the same forest $\sim 1 \mathrm{~km}$ southwest of the measurement site. A full complement of climate, flux, and forest characterization data is available at the Ameriflux site.

\section{Results and discussion}

This chapter will be divided into two parts. The first subsection will provide discussion of all days of the campaign, categorised into 4 classes. Parameters that favour the formation of new particles at the experimental site will be investigated. The second subsection will provide discussion of four days on which new particle formation was observed; detailed analysis of nucleation and growth on these days will be presented.

\subsection{Overview of all campaign days}

Here we present general results and discussion for the 32 intensive campaign days (25 June-26 July 2006). Using TDMPS data each of the 32 days was classified into one of the following four categories based on the occurrence and clarity of NPF events: A-event days, B-event days, undefined, and non-event days. The classification of the events was done in the same way as described in detail in Boy et al. (2002) by including one category for undefined days, which showed signs for new particle formation but could not be declared as an event day. On A-event days, nucleation mode particles $\left(D_{p}=3-20 \mathrm{~nm}\right)$ were clearly observed, as well as the continuous growth of these particles to Aitken mode $\left(D_{p}=20-100 \mathrm{~nm}\right)$. Only two of such events were observed on days for which TDMPS data are available. On the eight B-event days, nucleation mode particles with diameters smaller than $6 \mathrm{~nm}$ were not observed; however, nucleation mode particles $>6 \mathrm{~nm}$ and growth of these particles to Aitken mode were observed. The lack of observed particles $<6 \mathrm{~nm}$ on B-event days suggests that nucleation and growth began upwind of the measurement site. With an average growth rate of $4 \mathrm{~nm} \mathrm{~h}^{-1}$ for nucleation mode particles (see Secti. 3.2.1.) and mean wind speeds of $3 \mathrm{~m} \mathrm{~s}^{-1}$, the observed particles appear to have grown from clusters formed 

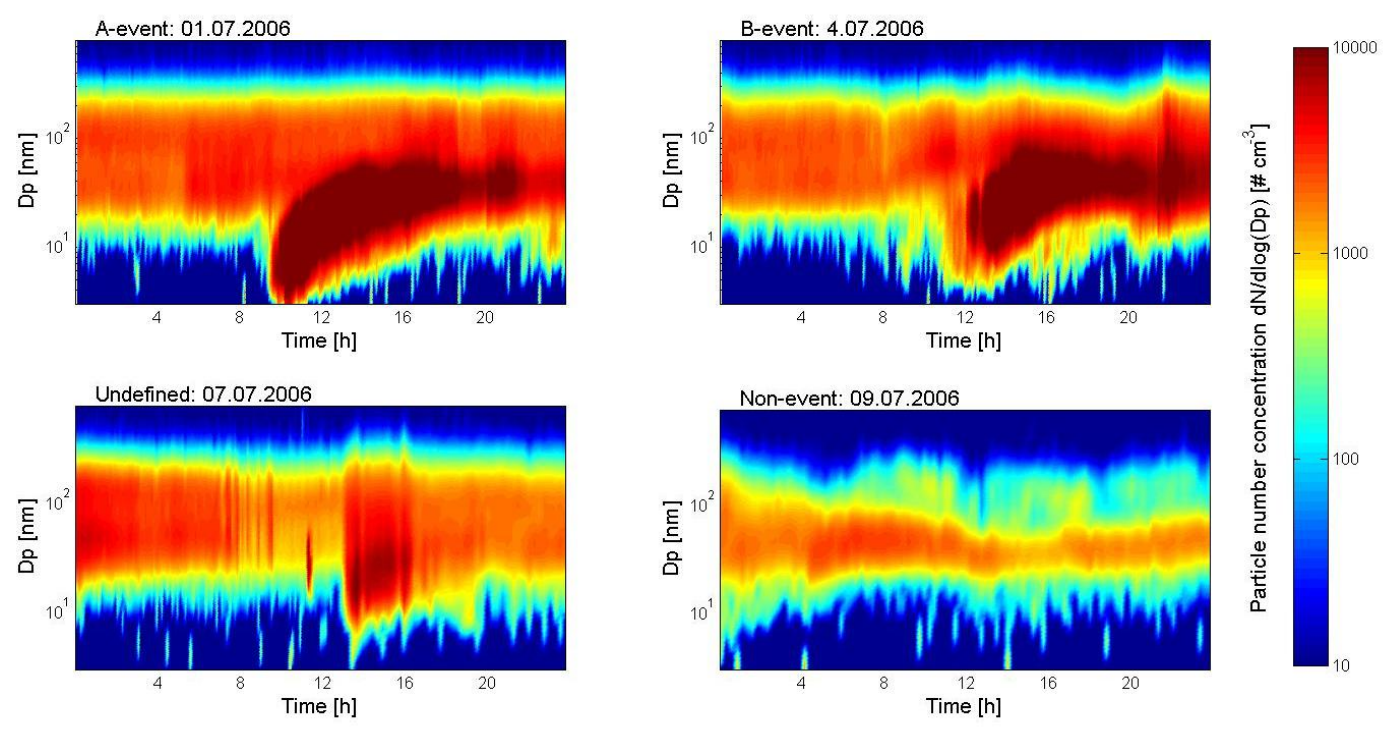

Fig. 2. Aerosol number size distributions from the TDMPS system without thermodenuder - examples for the 4 different event classifications.

approximately $10-15 \mathrm{~km}$ upwind, along the forested Front Range of the Colorado Rockies, downwind from the Denver municipal area (see Fig. 1). On the eight undefined days, some signs of NPF were observed. However, neither a significant fraction of nucleation mode particles nor the growth of the particles to Aitken mode was detected. On the 14 nonevent days, no signs of NPF were observed. An example of each type of event day is shown in Fig. 2.

Given that the mechanisms of new particle formation and growth are not known, it is useful to compare parameters such as temperature and sulphuric acid concentration among the four types of event days in order to determine which parameters are significantly correlated with NPF. For each of the 32 intensive campaign days, Table 1 lists the classification and mean values of ten potentially relevant parameters (averaged over the time interval in which NPF was observed, 10:00-16:00 h). Also included in the lower part of the table are the mean values of these parameters for the four event day categories. Figures 3 and 4 illustrate the daily pattern of selected parameters for each category. From these figures it can be seen that of all the investigated meteorological parameters, only relative humidity (RH) exhibited an apparent difference with NPF event days versus non-event days. On event days, nighttime RH was approximately $20 \%$ lower the preceding night and showed a distinctively stronger decrease after sunrise compared to non-event days. This difference is in agreement with earlier results published by Boy and Kulmala (2002), Bonn et al. (2002), Bonn and Moortgat (2003) and Hyvönen et al. (2005), and will be discussed further in Sect. 3.2.2.

During the A-event days there is an abrupt change from westerly to easterly wind direction early in the morning, whereas during all other types of event days a gradual tran- sition in wind direction is observed throughout the morning (Fig. 3). This is most likely due to the variability of the actual transition times, occurring anytime between mid-morning to early afternoon. Accompanying the easterly flow on all days was an increase in anthropogenically emitted trace gases (e.g., $\mathrm{SO}_{2}$ in Fig. 4) and aerosol loading (condensation sink in Fig. 3). Similar trends in wind direction and pollutant concentrations have been reported for past studies at or near this site (e.g. Parrish et al., 1990). The condensation sink values (CS - calculation based on dry particle diameter; see Boy et al., 2003), which reflect the amount of existing aerosol, were higher in anthropogenically influenced air masses and therefore higher on A-event days. This is in contrast to other stations where the CS values are lower during the event days compared to the non-event days (Boy et al., 2003; Birmilli et al., 2004; Hyvönen et al., 2005; Dal Maso et al., 2006, Wu et al., 2007). These results indicate that pre-existing aerosol loading is not one of the limiting factors at the measurement site; other parameters, such as the concentration of sulphuric acid, appear to play a more significant role in NPF. For example, sulphuric acid is up to a factor of 2 higher during B-event days compared to non-event days (Fig. 4). It should be noted here that no sulphuric acid data are available for A-event days. In addition, the concentrations of mono- and sesquiterpenes are higher during the B-event days and may also be important parameters for NPF.

\subsection{Analysis of 4 NPF-days}

Here we present a more detailed discussion of four days in which NPF was clearly observed. During the intensive campaign, most of the instrumentation described in Sect. 2 was running continuously; however during the two A-event days, no sulphuric acid measurements were available. The 
Table 1. Classification of all days and average values of selected parameters between 10 a.m. and 4 p.m.; included in the lower part are the average values for the same parameters for the defined event classes and in brackets the average number included for each time step in the daily pattern for each category ( $\mathrm{CS}=$ condensation sink; MT = concentration of monoterpenes; $\mathrm{SQT}=$ concentration of sesquiterpenes).

\begin{tabular}{|c|c|c|c|c|c|c|c|c|c|c|c|}
\hline Date & Event-classification & $\begin{array}{c}N_{\text {total }} \\
{\left[{\left.\mathrm{\#} \mathrm{cm}^{-3}\right]}\right]}\end{array}$ & $\begin{array}{c}N_{<6 \mathrm{~nm}} \\
{\left[\# \mathrm{~cm}^{-3}\right]}\end{array}$ & $\begin{array}{l}N_{<10 \mathrm{~nm}} \\
{\left[\# \mathrm{~cm}^{-3}\right]}\end{array}$ & $\begin{array}{c}\mathrm{CS} \\
10^{-3} \times \\
{\left[\mathrm{s}^{-1}\right]}\end{array}$ & $\begin{array}{l}\text { Temp. } \\
{\left[{ }^{\circ} \mathrm{C}\right]}\end{array}$ & $\begin{array}{l}\mathrm{RH} \\
{[\%]}\end{array}$ & $\begin{array}{c}\mathrm{SO}_{2} \\
10^{9} \times \\
{\left[\# \mathrm{~cm}^{-3}\right]}\end{array}$ & $\begin{array}{c}\mathrm{H}_{2} \mathrm{SO}_{4} \\
10^{6} \times \\
{\left[\# \mathrm{~cm}^{-3}\right]}\end{array}$ & $\begin{array}{c}\text { MT } \\
10^{10} \times \\
{\left[\# \mathrm{~cm}^{-3}\right]}\end{array}$ & $\begin{array}{c}\text { SQT } \\
10^{8} \times \\
{\left[\# \mathrm{~cm}^{-3}\right]}\end{array}$ \\
\hline $6 / 25$ & B-event & 8314 & 70 & 534 & 5.4 & 11.0 & 75.4 & 3.1 & 3.66 & 0.49 & 4.79 \\
\hline $6 / 27$ & A-event & NA & NA & NA & NA & 17.0 & 27.6 & 4.2 & NA & 0.93 & 4.71 \\
\hline $6 / 28$ & Non-event & 2540 & 10 & 69 & 3.3 & 17.7 & 29.4 & 1.1 & 2.10 & 0.59 & 4.71 \\
\hline $6 / 29$ & Undefined & 3237 & 59 & 287 & 3.1 & 17.2 & 37.3 & 0.5 & 0.88 & 0.68 & 5.72 \\
\hline $7 / 2$ & Undefined & 8834 & 83 & 399 & 6.1 & 17.4 & 52.3 & 4.8 & 2.72 & NA & NA \\
\hline $7 / 3$ & Non-event & 5617 & 77 & 270 & 4.9 & 14.8 & 65.6 & 3.2 & 1.85 & NA & NA \\
\hline $7 / 4$ & B-event & 11694 & 58 & 446 & 6.2 & 15.1 & 69.8 & 6.9 & 3.18 & NA & NA \\
\hline $7 / 5$ & Non-event & 5180 & 15 & 86 & 7.2 & 12.9 & 80.8 & 2.7 & 0.71 & NA & NA \\
\hline $7 / 6$ & Undefined & 3410 & 16 & 93 & 3.5 & 16.8 & 59.5 & 2.0 & 1.94 & NA & NA \\
\hline $7 / 7$ & Undefined & 6581 & 19 & 169 & 3.9 & 19.0 & 45.6 & NA & NA & NA & NA \\
\hline $7 / 8$ & Non-event & 2298 & 14 & 61 & 2.8 & 10.1 & 95.3 & NA & NA & 1.25 & 4.33 \\
\hline $7 / 13$ & Non-event & 3077 & 32 & 71 & 6.3 & 21.4 & 20.9 & 2.6 & 2.24 & 1.78 & 4.23 \\
\hline $7 / 14$ & B-event & 19042 & 663 & 3210 & 5.6 & 23.7 & 18.7 & 6.3 & 9.25 & 1.64 & 4.06 \\
\hline $7 / 15$ & B-event & 3981 & 110 & 402 & 3.7 & 25.5 & 13.6 & 1.9 & 3.03 & 2.41 & 6.17 \\
\hline $7 / 16$ & B-event & 8110 & 407 & 1982 & 4.5 & 24.9 & 17.1 & 3.1 & 4.77 & 2.48 & 16.19 \\
\hline $7 / 17$ & B-event & 14597 & 246 & 1537 & 6 & 20.1 & 38.5 & 4.4 & 5.31 & 2.48 & 6.38 \\
\hline $7 / 18$ & Non-event & 4642 & 31 & 298 & 4.4 & 23.0 & 24.8 & 2.6 & 4.11 & 1.73 & 5.41 \\
\hline $7 / 19$ & Non-event & 3216 & 41 & 328 & 3.7 & 20.9 & 35.2 & 1.4 & 2.76 & 1.77 & 4.87 \\
\hline $7 / 20$ & Non-event & 4444 & 34 & 209 & 4.9 & 19.9 & 50.3 & 2.8 & 3.10 & 1.40 & 5.04 \\
\hline $7 / 21$ & Undefined & 4064 & 31 & 315 & 4.7 & 16.9 & 58.6 & 2.1 & 3.03 & 1.70 & 4.32 \\
\hline $7 / 22$ & Undefined & 9611 & 213 & 882 & 5.9 & 19.9 & 44.4 & 4.5 & 4.47 & 0.92 & 2.95 \\
\hline $7 / 23$ & Undefined & 5231 & 74 & 377 & 4.9 & 22.7 & 28.1 & 3.4 & 1.52 & 1.18 & 4.18 \\
\hline $7 / 24$ & Non-event & 2881 & 34 & 118 & 4.6 & 20.8 & 38.4 & 2.2 & 0.88 & 1.53 & 3.98 \\
\hline $7 / 25$ & B-event & 10464 & 126 & 906 & 4.3 & 18.0 & 56.4 & 4.5 & 3.05 & 1.88 & 4.10 \\
\hline
\end{tabular}

four B-event days chosen for more detailed discussion (highlighted bold in Table 1) were days on which NPF was clearly observed and data were available from all instruments.

\subsubsection{Growth rates}

In order to parameterize the temporal behaviour of aerosol particle modes, multiple log normal curves were fitted to each individual particle size distribution using an algorithm with a multi log normal distribution function (Hussein et al., 2005). In this work emphasis was on generating continuous time series of modal parameters, especially for the nucleation mode in terms of the mean diameter $D_{\mathrm{p} \text {-nuc }}$. A graph for each of the four selected event days based on measured particle size distributions without and with TD is shown in Fig. 5. As mentioned previously, on most of the B-event days the smaller nucleation mode particles were not detected. Therefore, the automatic fitting program could not detect the mean nucleation mode diameter below $10 \mathrm{~nm}$ for the size distributions without TD. The estimated mean nucleation mode diameter after thermal treatment could be defined between 4 and $8 \mathrm{~nm}$ (see Fig. 5). Since only the compounds of lowest volatility remain after thermal treatment of $300^{\circ} \mathrm{C}$, the remainder may be considered a marker for non-volatile organic compounds (e.g. oligomers).

By assuming a constant growth of particles in the nucleation mode (Kulmala et al., 2004) we interpolated the curves for each day down to the size of $1 \mathrm{~nm}$ for $D_{\mathrm{p} \text {-nuc }}$ (dashed lines in Fig. 5). These assumptions enabled the calculations of growth rates based on the TDMPS data measured without and with TD. Furthermore, we can calculate the particle 

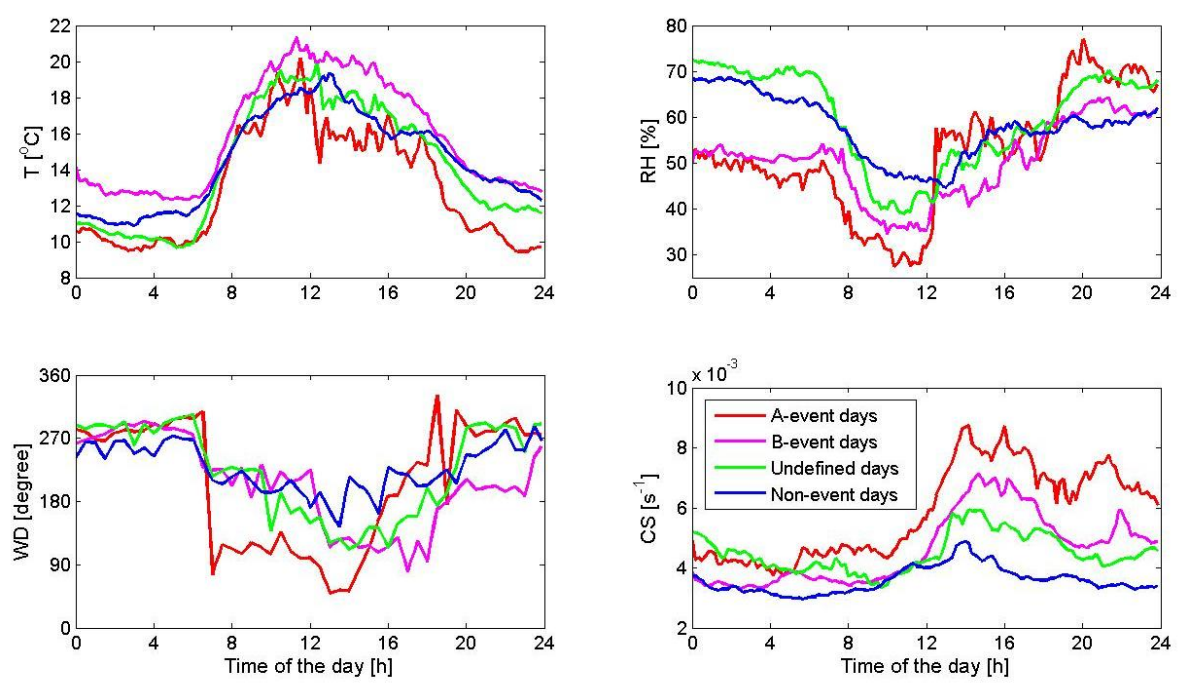

Fig. 3. Temperature, relative humidity, wind direction and condensation sink (CS) daily pattern for the defined categories (see text). The number of days included for the calculations of each parameter by following the order of the legend is: $2,8,8$ and 14 .
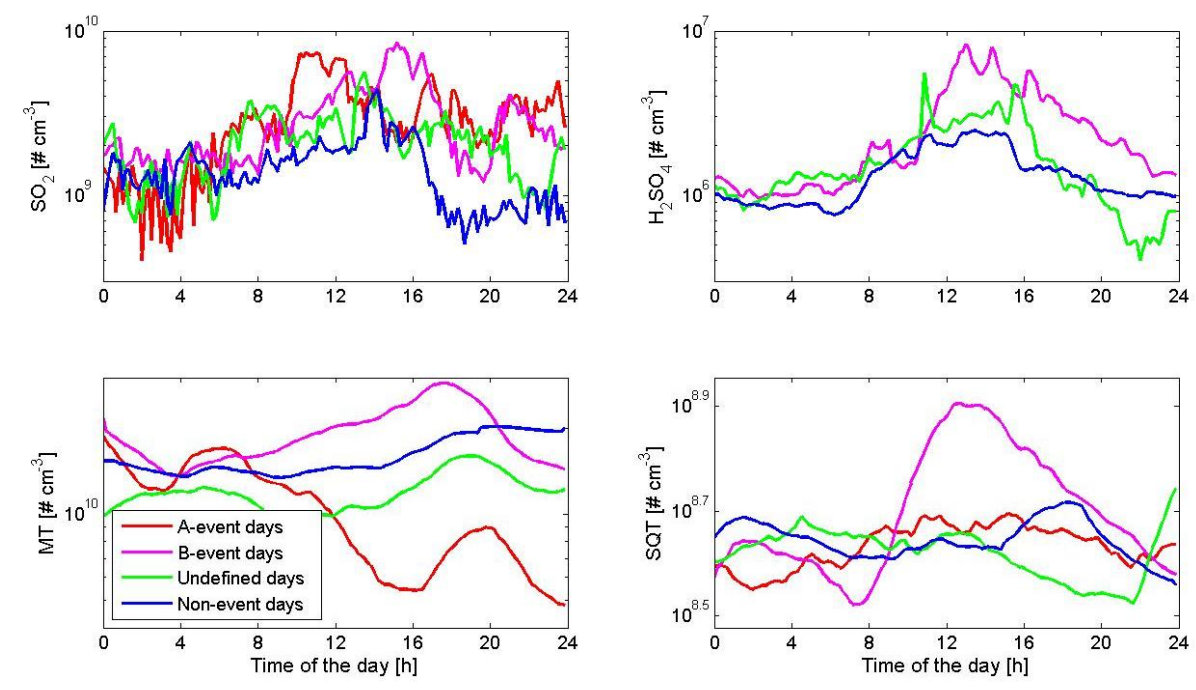

Fig. 4. Daily pattern of several gas concentrations for the defined event categories (MT = monoterpenes, SQT = sesquiterpenes). The number of days included for the calculations by following the order of the legend is: $\mathrm{SO}_{2}: 2,7,7,10 ; \mathrm{H}_{2} \mathrm{SO}_{4}: 0,4,3,9 ;$ terpenes: $1,7,5$ and 12 .

diameter growth rates (Kulmala et al., 2001) from the measured sulphuric acid concentrations $\left(C_{\mathrm{H}_{2} \mathrm{SO}_{4}}\right)$ by

$\frac{d D_{p-\mathrm{H}_{2} \mathrm{SO}_{4}}}{d t}=\frac{4 m_{\mathrm{H}_{2} \mathrm{SO}_{4}} \beta_{m} D_{\mathrm{H}_{2} \mathrm{SO}_{4}}}{C_{\mathrm{H}_{2} \mathrm{SO}_{4}} D_{p} \rho_{p}}$

Here $m_{\mathrm{H}_{2} \mathrm{SO}_{4}}$ is molecular mass, $\beta_{m}$ is the transitional correction factor for the mass flux (Fuchs and Sutugin, 1971), $D_{\mathrm{H}_{2} \mathrm{SO}_{4}}$ is the diffusion coefficient and $\rho_{p}$ is the liquid density. This equation is derived for spherical nucleation mode particles from macroscopic condensation theory, and does not hold for 1-3 nm sized particles. Lehtinen and Kulmala (2003) have considered condensation at molecular resolution and found that condensation is enhanced at small particle sizes compared with the macroscopic treatment. According to calculations made with an aerosol dynamic model UHMA (Korhonen et al., 2004), for 1-3 nm particles the condensation rate is enhanced by a factor between 2 and 3 compared with the value obtained by Eq. (1).

In Fig. 6 three estimated diurnal growth curves, $D_{\text {p-nuc }}$ with and without TD and $D_{\mathrm{p}-\mathrm{H}_{2} \mathrm{SO}_{4}}$, are presented for each day. The thin vertical black lines indicate the time when the mean nucleation mode diameter reached $5,10,15,20,25$ and $30 \mathrm{~nm}$ (and $35 \mathrm{~nm}$ for the 15 and 17 July). The overall average growth rates of particles measured by the TDMPS 
system without TD (solid black line) in the size range of 1$15 \mathrm{~nm}$ was $3.96 \mathrm{~nm} \mathrm{~h}^{-1}$ for all 4 days. Between 15 and $30 \mathrm{~nm}$ these growth rates always exhibited a short minimum and an increase afterwards to mean value of $3.02 \mathrm{~nm} \mathrm{~h}^{-1}$. On the first and third day the same pattern is visible for the data with thermal treatment (dashed black line). The other two days did not show a minimum in the growth rate. However, the minimum in the solid black line on the 15th occurred at the time when we interpolated the growth rates for data measured with TD. It is unclear why there is a minimum in the growth rates at the edge between the nucleation and Aitken mode particles. It can not be explained by vertical mixing processes because the collapse of the boundary layer does not occur when the minimum is observed, between 14 and $17 \mathrm{~h}$. Before midnight all profiles feature a second minimum in growth rates (see Fig. 5). We speculate that both minima could depend on the onset of changing chemistry, since solar zenith angle is declining; and/or a reduction in terpene emissions with decreasing temperature and ongoing emptying of the storage pools within the needles or leaves as a consequence on the strong emission beforehand; however, chemical size dependent analysis would be necessary to explore these phenomena.

Sulphuric acid seems to contribute between 5 and 25 percent to the growth of particles in the nucleation mode, decreasing as the particle reached the size of the Aitken mode. If we consider the assessment of Korhonen et al. (2004), the measured sulphuric acid concentrations could be responsible for approximately 10 to $75 \%$ of the growth until the particles reached $3 \mathrm{~nm}$.

Figure 7 gives the ratio of the growth rates estimated from the TDMPS data with and without TD between 1 and $26 \mathrm{~nm}$ (estimated with the interpolated growth rates in Fig. 5) for the 17 and 25 July. Also included are the concentrations of sesquiterpenes for the equivalent time intervals. The graphs indicate a relation between both parameters on both days. No correlations with other parameters such as sulphuric acid or other organic species with the ratio of the growth rates were found. This result suggests that higher terpenoid compounds such as sesquiterpenes could be responsible for forming larger organic molecules which would not evaporate after thermal treatment of $300^{\circ} \mathrm{C}$. The existence of such molecules in laboratory experiments (chamber studies) has been reported (e.g. Kalberer et al., 2004), however our results are one of the first for atmospheric aerosols (see also Kalberer et al., 2006; Surrat et al., 2007; Iinuma et al., 2007), and indicate that the reaction products of sesquiterpenes are likely involved in the observed growth of atmospheric aerosols up to a certain particle diameter.

\subsubsection{Nucleation rates}

Here we focus on formation rates of particles in the 6-10 nm size range (range for which TDMPS data are available for Bevent days) and the related formation rates of $2 \mathrm{~nm}$ particles.

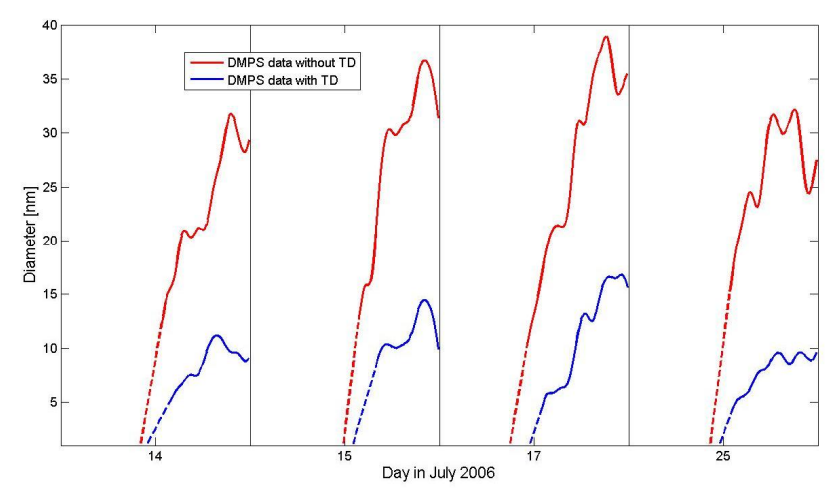

Fig. 5. Evolution of geometric mean diameter (solid line) and linear fit (dashed line) of nucleation mode without and with TD during selected nucleation event days ( $\mathrm{x}$-axis from midnight to midnight for each day).

Particles in this size range are small enough to be considered freshly nucleated (1-1.5 h after nucleation) but large enough to be sampled more efficiently, allowing for better statistics and reduction of the influence of measurement uncertainties. The particle number concentration in this size range is denoted by $N_{6-10}$. The time evolution of $N_{6-10}$ is described with a balance equation

$\frac{d N_{6-10}}{d t}=\mathrm{GR}_{6 \mathrm{~nm}} \cdot n_{6 \mathrm{~nm}}-\mathrm{GR}_{10 \mathrm{~nm}} \cdot n_{10 \mathrm{~nm}}-\mathrm{CoagS}_{6-10} \cdot N_{6-10}$

including terms for growth into the $6-10 \mathrm{~nm}$ range over the $6 \mathrm{~nm}$ barrier $\left(\mathrm{GR}_{6 \mathrm{~nm}}\right)$, out over the $10 \mathrm{~nm}$ barrier $\left(\mathrm{GR}_{10 \mathrm{~nm}}\right)$ and loss by coagulation scavenging $\left(\mathrm{CoagS}_{6-10}\right)$ (Kulmala et al., 2001). The function $\mathrm{n}$ is a particle size distribution function, defined as $n=d N / d d_{p}$ with $d_{p}=$ particle diameter. By rearranging the terms, and denoting the first term on the right hand side of Eq. (2) as $J_{6 \text {-TDMPS }}$, the following equation is obtained:

$J_{6-\mathrm{TDMPS}}=\frac{d N_{6-10}}{d t}+\mathrm{CoagS}_{d_{p}=8 \mathrm{~nm}} \cdot N_{6-10}+\frac{1}{4 \mathrm{~nm}} \cdot \mathrm{GR}_{10 \mathrm{~nm}} \cdot N_{6-10}$

$J_{6-T D M P S}$ is the apparent nucleation rate (i.e. the formation rate of new particles above $6 \mathrm{~nm}$ ). The first term on the right hand side is directly obtained from the TDMPS data. The coagulation loss for the interval $6-10 \mathrm{~nm}$ has been approximated by a term representing loss of $8 \mathrm{~nm}$ sized particles with concentration $N_{6-10}$. CoagS $\mathrm{S}_{d p=8 \mathrm{~nm}}$ is directly calculated from the measured background particle size distribution. The third term, representing loss due to condensation out of the 6-10 nm size range, comes from measured $N_{6-10 \mathrm{~nm}}$ and the calculated growth rates described in Sect. 3.2.1.

With the estimated formation rate $J_{6 \text {-TDMPS }}$, the nucleation rate $J_{2 \text {-TDMPS }}$ for particles with $2 \mathrm{~nm}$ diameter at the time $t=t^{\prime}-\Delta t$ can be estimated using the method presented by Kerminen and Kulmala (2002):

$J_{2-\operatorname{TDMPS}}(t)=J_{6}\left(t^{\prime}\right) \cdot \exp \left(\gamma \cdot \frac{\mathrm{CS}^{\prime}}{\mathrm{GR}} \cdot\left(\frac{1}{2 \mathrm{~nm}}-\frac{1}{6 \mathrm{~nm}}\right)\right)(4)$ 

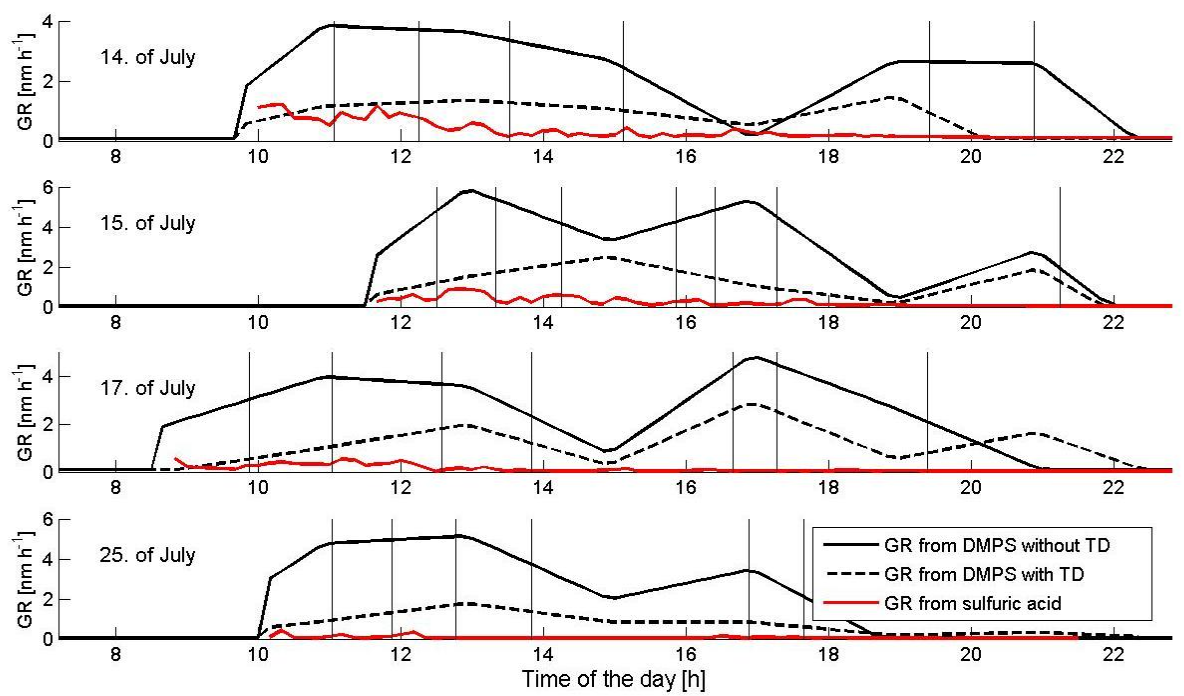

Fig. 6. Detected growth rates (GR) of the mean nucleation mode diameter from the TDMPS data without and with TD; calculated GR through sulfuric acid. The light vertical black lines indicate the times, when the mean nucleation mode particles reached diameters of 5,10 , $15,20,25,30$ and $(35) \mathrm{nm}$.

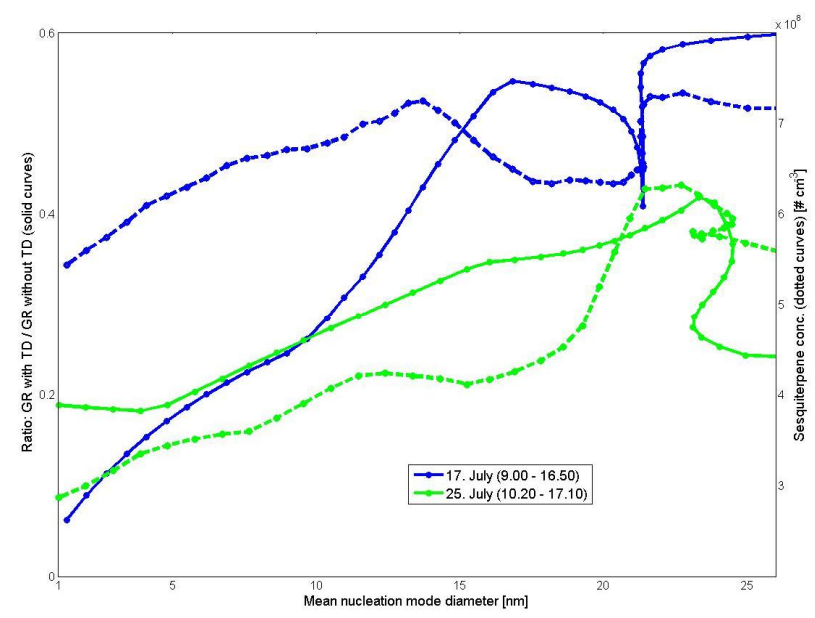

Fig. 7. Ratio of growth rates determined with and without thermodenuder (solid lines) and concentrations of sesquiterpenes (dashed lines) for two event days (time step $10 \mathrm{~min}$ for each point).

Here CS' is the condensation sink (in $\mathrm{m}^{-2}$ ), GR is the growth rate calculated in Sect. 3.2.1 (in $\mathrm{nm} \mathrm{h}^{-1}$ ) and $\gamma$ is a coefficient with a value of $0.23 \mathrm{~m}^{2} \mathrm{~nm}^{2} \mathrm{~h}^{-1}$. With the growth rate described in Sect. 3.2.1 the time interval $\Delta t$ was calculated for each time step. Mean values for CS' and GR over the time interval $\Delta t$ are used in Eq. (4).

According to recently published results by Sihto et al. (2006) and Riipinen et al. (2007) we investigated the correlation of particles $N_{6-10 \mathrm{~nm}}$ with measured sulphuric acid concentrations. Figure 8 presents the logarithm of both values for the 4 selected days between 10 a.m. and 4 p.m. Sim-

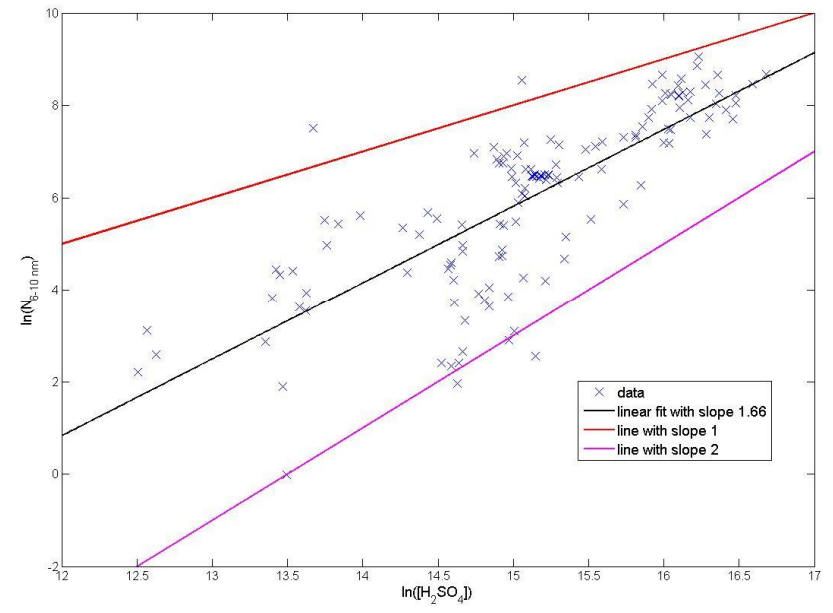

Fig. 8. Logarithm of the number concentration of 6-10 nm particles $\left(N_{6-10}\right)$ versus logarithm of the sulphuric acid concentration for all 4 days. Linear fit to the data by the method of least squares and lines corresponding relationships $N_{6-10}-\left[\mathrm{H}_{2} \mathrm{SO}_{4}\right]$ and $N_{6-10}-$ $\left[\mathrm{H}_{2} \mathrm{SO}_{4}\right]^{2}$ are shown.

ilar to the results in the two publications mentioned, we can estimate an exponent for the correlation $N_{6-10 \mathrm{~nm}}=\left(\mathrm{H}_{2} \mathrm{SO}_{4}\right)^{\mathrm{x}}$ by the slope of the scatter plot. Most of the data fit between two lines with slope 1 or 2 , indicating linear or quadratic dependence of the newly formed particles on sulphuric acid concentration. A least squares fit to the data gives 1.66 for the exponent, which is noticeably higher than the value of 1.24 published by Sihto et al. (2006) for Hyytiälä. This result would involve a higher contribution of sulphuric acid in 
the nucleation mechanism at the site of research compared to Hyytiälä.

Based on these results we will use three different nucleation mechanisms to calculate $J_{2}$ values for comparison with formation rates based on the TDMPS measurements. The first mechanism is called "activation type nucleation" and was first proposed by Kulmala et al. (2006) and further investigated using data from the SMEAR II Station (Station for Measuring Ecosystem-Atmosphere Relation) in Hyytiälä by Sihto et al. (2006) and Riipinen et al. (2007). Nucleation is thought to happen as activation of small clusters containing one sulphuric acid molecule occurs, via heterogeneous chemical reactions for example. Because critical clusters are assumed to contain one sulphuric acid molecule, the nucleation rate is directly proportional to the sulphuric acid concentration.

$$
J_{2-\text { act }}=A\left[\mathrm{H}_{2} \mathrm{SO}_{4}\right]
$$

The coefficient $A$ was determined for our 4 days according to the $J_{2}$ values calculated above and listed in Table 2. The activation coefficient $A$ contains the physics and chemistry of the nucleation process; however, so far it is only an empirical coefficient which needs further investigation.

The second mechanism is called "kinetic type nucleation" and was first proposed by McMurry and Friedlander (1979). In kinetic nucleation, critical clusters are formed by collisions of sulphuric acid molecules or other molecules containing sulphuric acid, e.g. ammonium bisulphate molecules. The upper limit for kinetic nucleation, the so called "kinetic limit", is set by the collision rate of molecules given by the kinetic theory of gases. Here we let the collision frequency function be a free parameter and calculate nucleation rate as:

$$
J_{2-\mathrm{kin}}=K\left[\mathrm{H}_{2} \mathrm{SO}_{4}\right]^{2}
$$

Where, similar to the "activation theorem", the coefficient $K$ (also listed in Table 2) will be adjusted to fit $J_{2}$ values calculated above. This kinetic coefficient $K$ contains the details of the nucleation process, specifically the probability that a collision of two sulphuric acid containing molecules results in the formation of a stable critical cluster.

The average estimated $A$ - and $K$-coefficients calculated from this study (Table 2 ) have similar mean values, $\sim a$ factor of 1 and 3 higher, compared to the Quest IV campaign in Hyytiala (Riipinen et al., 2007). During an earlier campaign at the same site (Quest II) the published values were a factor of 6 and 30 higher, respectively. Taking into account the uncertainties of the measurements and calculations, sulfuric acid seems to participate in similar ways in new particle formation mechanism at both sites. A more diverse picture emerges when comparing average $A$ - and $K$-coefficients from this study with values obtained at a more polluted site near Heidelberg in Southern Germany (Fiedler et al., 2005). The $A$ - and $K$-coefficients were 280 and 1200 times higher near Heidelberg despite similar magnitudes of sulfuric acid
Table 2. Calculated $A$ - and $K$-values for two nucleation theorems (see text) for 4 selected event days at the Mountain Research Station (MRS) $-{ }^{\mathrm{a}}$ data for comparison from earlier publication by Riipinen et al. (2007).

\begin{tabular}{lcc}
\hline & $A$-values & $K$-values \\
\hline 14 July - MRS & $5.00 \mathrm{E}-07$ & $2.50 \mathrm{E}-14$ \\
15 July - MRS & $1.00 \mathrm{E}-07$ & $8.00 \mathrm{E}-15$ \\
17 July - MRS & $2.50 \mathrm{E}-07$ & $2.50 \mathrm{E}-14$ \\
25 July - MRS & $2.50 \mathrm{E}-07$ & $1.50 \mathrm{E}-14$ \\
Mean - MRS & $2.75 \mathrm{E}-07$ & $1.83 \mathrm{E}-14$ \\
Hyytiala Quest II $^{\mathrm{a}}$ & $1.70 \mathrm{E}-06$ & $5.70 \mathrm{E}-13$ \\
Heidelberg Quest III $^{\mathrm{a}}$ & $7.70 \mathrm{E}-05$ & $2.30 \mathrm{E}-11$ \\
Hyytiala Bacci/Quest IV $^{\mathrm{a}}$ & $3.50 \mathrm{E}-07$ & $5.50 \mathrm{E}-14$ \\
\hline
\end{tabular}

concentrations $\left(3.46 \times 10^{6} \mathrm{~m} \mathrm{~cm}^{-3}\right.$ during Quest III near Hei-

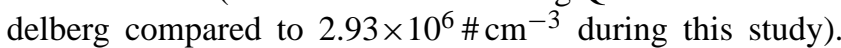
The main reason for huge discrepancies of the $A$ - and $K$ coefficients at the two sites is likely related to different mechanisms in NPF processes. This could indicate that other molecules besides sulphuric acid play an important role at different locations depending on the degree of anthropogenic and biogenic influences.

The third mechanism will be called "nucleation by activation of organic molecules" and is a simplification of a nucleation mechanism recently published by Bonn et al. (2007 and $2008^{1}$ ). In this mechanism we calculate the concentrations of stabilised Criegee Intermediates (sCI) from the reaction of sesquiterpenes with ozone. In order to do so, a chemical steady state concentration for the sCIs is assumed, in which the source (sesquiterpene + ozone)*stabilisation ratio equals the sink (ambient conditions: mainly reaction with water vapour).

$[\mathrm{sCI}]=\frac{k_{1} *\left[\mathrm{O}_{3}\right] *\left[\mathrm{C}_{15} \mathrm{H}_{24}\right] * 0.94}{k_{2} *\left[\mathrm{H}_{2} \mathrm{O}\right]}$

In this formula $[\mathrm{sCI}],\left[\mathrm{O}_{3}\right],\left[\mathrm{C}_{15} \mathrm{H}_{24}\right]$ and $\left[\mathrm{H}_{2} \mathrm{O}\right]$ are the concentrations of stabilised Criegee intermediates, ozone, sesquiterpenes and water vapour in molecules per $\mathrm{cm}^{3}$. The reaction rate coefficient of sesquiterpenes with ozone $k_{1}$ is $1.16 \times 10^{-14} \mathrm{~cm}^{3}$ molecule ${ }^{-1} \mathrm{~s}^{-1}(\beta$-caryophyllene, Shu and Atkinson (1994)). The stabilisation ratio is $0.94(6 \% \mathrm{OH}$ yield, Shu and Atkinson (1994)) and the reaction rate of the sCIs with water vapour $k_{2}$ is $1 \times 10^{-17} \mathrm{~cm}^{3}$ molecule ${ }^{-1} \mathrm{~s}^{-1}$ (Grossmann, 1999). Besides its reaction with ambient water vapour the sCIs can react with sulphuric acid to form an organic sulphate (Org_Sul) or with another organic molecule (e.g. aldehyde) to form a secondary ozonide (SOZ).

Org_Sul $=k_{3} *[\mathrm{sCI}] *\left[\mathrm{H}_{2} \mathrm{SO}_{4}\right] /\left(1 / \tau_{\text {chem, Org_Sulf }}+\mathrm{CS}\right)$

${ }^{1}$ Bonn, B., Kulmala, M., Riipinen, I., Sihto, S.-L., and Russkanen, R. M.: Linking the connection of sulphuric acid and new particle formation to biogenic terpenes, J. Geophys. Res., submitted, 2008 . 


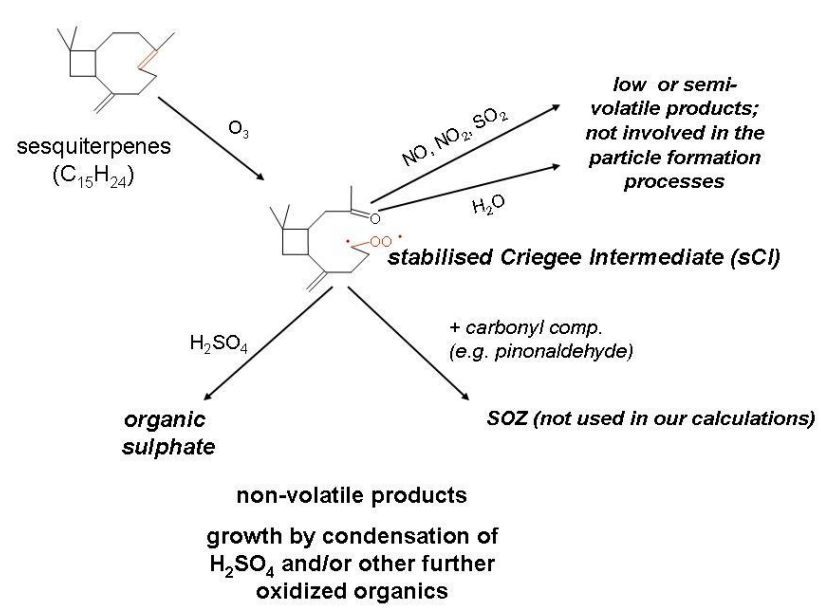

Fig. 9. Schematic picture of the nucleation mechanism by activation of organic molecules.

$$
\left.\mathrm{SOZ}=k_{4} *[\mathrm{SCI}] * \text { aldehydes }\right] /\left(1 / \tau_{\text {chem }, \mathrm{SOZ}}+\mathrm{CS}\right)
$$

Here $k_{3}$ represents the reaction rate of stabilized Criegee Intermediates with sulphuric acid $\left(k_{3}=k_{2} * 5 \mathrm{E} 4,50000\right.$ times faster than the reaction with $\mathrm{H}_{2} \mathrm{O}-$ Bonn et al., 2008 ${ }^{1}$ ) and $k_{4}$ stands for the reaction rate of one sCI molecule with ambient aldehydes $\left(k_{4}=k_{2} * 1000,1000\right.$ times faster than the reaction with $\mathrm{H}_{2} \mathrm{O}-$ Bonn et al., $2008^{1}$ ). The most abundant aldehyde is commonly formaldehyde (HCHO) with additional contributions of acetaldehyde and local aldehydes from monoterpene oxidation such as pinonaldehyde. $\tau_{\text {chem }, i}$ are the chemical lifetimes of organosulfate and secondary ozonide. If we assume these to be rather long lived, the condensation sink is the dominant term defining the ambient lifetime of $i$. $1 /\left(\tau_{\mathrm{chem}, i}+\mathrm{CS}\right)$ at the very end is the total lifetime of each compound before removal or destruction. The Org_Sul formed will have an atomic mass of $352 \mathrm{~g} \mathrm{~mol}^{-1}$ and will be able to grow by condensation. The atomic mass of the $\mathrm{SOZ}$ will be of a similar size, depending on the size of the aldehyde participating in the formation process. A complete use of the whole nucleation mechanism proposed by Bonn et al. $\left(2007\right.$ and $\left.2008^{1}\right)$ was not possible because some organic molecules included in the mechanism (aldehydes) were not measured during the campaign.

To calculate $J_{2 \_ \text {org }}$ values we used measured sesquiterpenes and sulphuric acid concentrations. Figure 9 gives a schematic picture of this mechanism and reflects the role of the water molecules in the gas phase. Water molecules react with the sCIs and inhibit the production of organic sulphates or secondary ozonides by production of hydroxyhydroperoxides, which subsequently decompose to more volatile and less reactive aldehydes); therefore, increasing water vapour will decrease the concentration of organic sulfates and secondary ozonides formed. This could explain the negative correlation between the occurrence of newly formed particles and relative humidity observed here and reported in earlier publications (Boy and Kulmala, 2002; Bonn et al., 2002; Bonn and Moortgat, 2003; Hyvönen et al., 2005).

Figure 10 presents all calculated $J_{2}$ values for the four selected days, including the time delay $\Delta t$ for the calculated

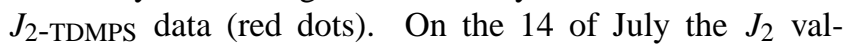
ues from the kinetic and organic activation theorem follow

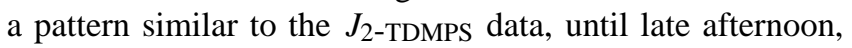
when both theories overestimate the formation rates. The activation theory strongly overestimates the $J_{2 \text {-TDMPS values }}$ in the morning and afternoon. During the mornings of the next two days, 15 and 17 July, the activation theory initially

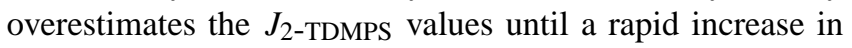

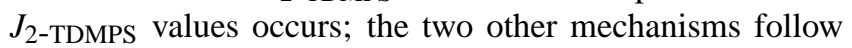

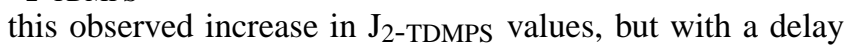
to around noon. In the afternoon, the kinetic and organic activation hypothesis follow the descent of the $J_{2 \text {-TDMPS data, }}$ while the activation theory values remain relatively constant. The pattern on the 25 July is more like that on the 14 July,

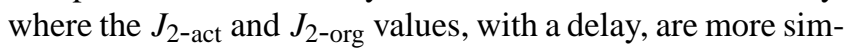

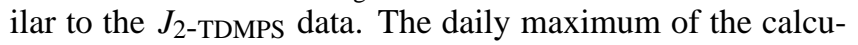

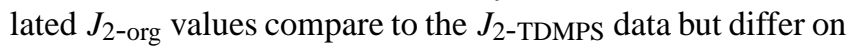
individual days by a factor of 2 to 5 in both directions. Here we note that the calculation of the $J_{2 \text {-org values is based only }}$ on a simplified mechanism because other organic molecules favouring or preventing particle formation are not considered due to the lack of measurements. Taking into account all four days, we could assert that each of the three calculated $J_{2}$ rates are at one time or another in good agreement with formation rates based on the TDMPS measurements. It is too early to make a final conclusion whether the empirically defined $A$ and $K$ coefficients from the activation and kinetic nucleation theory can be described by the presence of certain organic molecules, such as sesquiterpenes and their reaction products. However, our data analysis shows that on several occasions strong improvements in the prediction of the formation rates are achieved by the organic activation mechanism.

\subsubsection{Particle mass}

Here we focus on the total particle mass and mass change calculated from the TDMPS data without TD and sulphuric acid data (assuming a density of $1 \mathrm{~g} \mathrm{~cm}^{-3}$ for all aerosols). The upper plot of Fig. 11 presents the daily pattern of particle mass and wind direction for the four selected B-event days. On the 14 July NPF was observed at our measurement site (indicated by the blue thin line for each day) at the same time a change in wind-direction from west to southeast occurred. Aerosol mass increased continuously from a value of $2 \mu \mathrm{g} \mathrm{m}^{-3}$ during the night and early morning to $4 \mu \mathrm{g} \mathrm{m}^{-3}$ in the late afternoon. In the evening and during the night aerosol mass decreased again until it reached a slightly higher value in the morning of the next day compared to the night before. On the 15 July NPF was observed earlier, than the change in wind-direction. However, the increase in mass, although not as large as on the previous day, happened at the time as the 


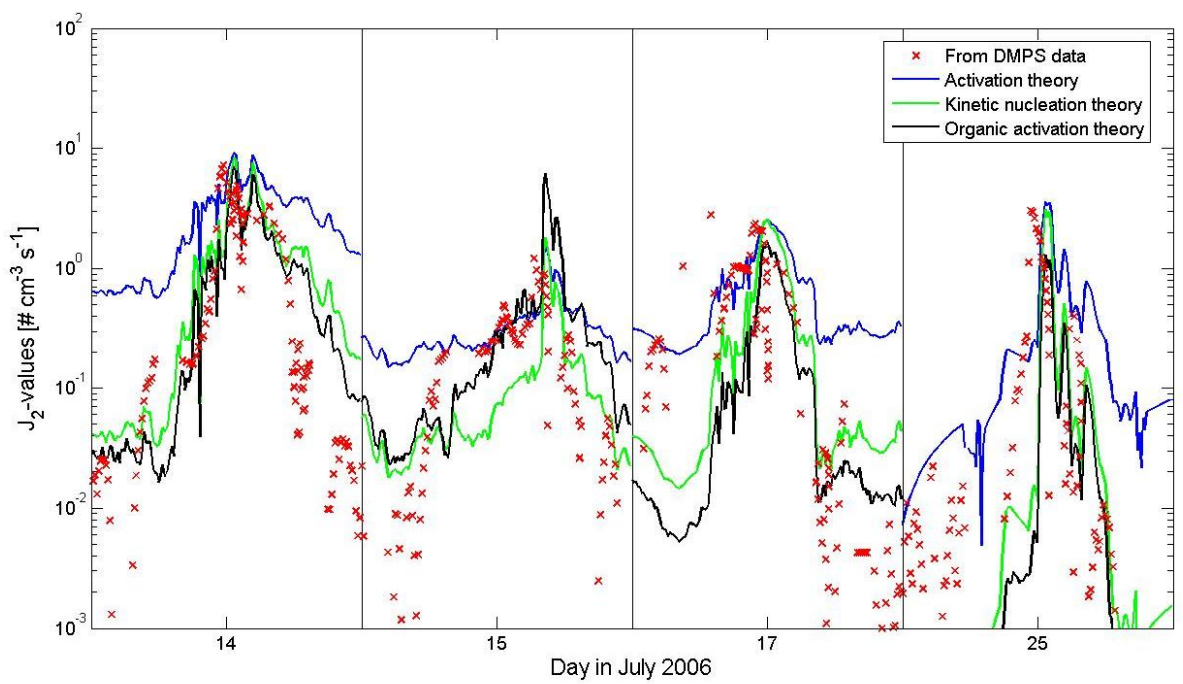

Fig. 10. Nucleation rate $\left(J_{2}\right)$ estimated from the particle measurements and calculated from the sulphuric acid concentration using three hypothetic nucleation mechanisms: "activation type", "kinetic type" and "organic activation".
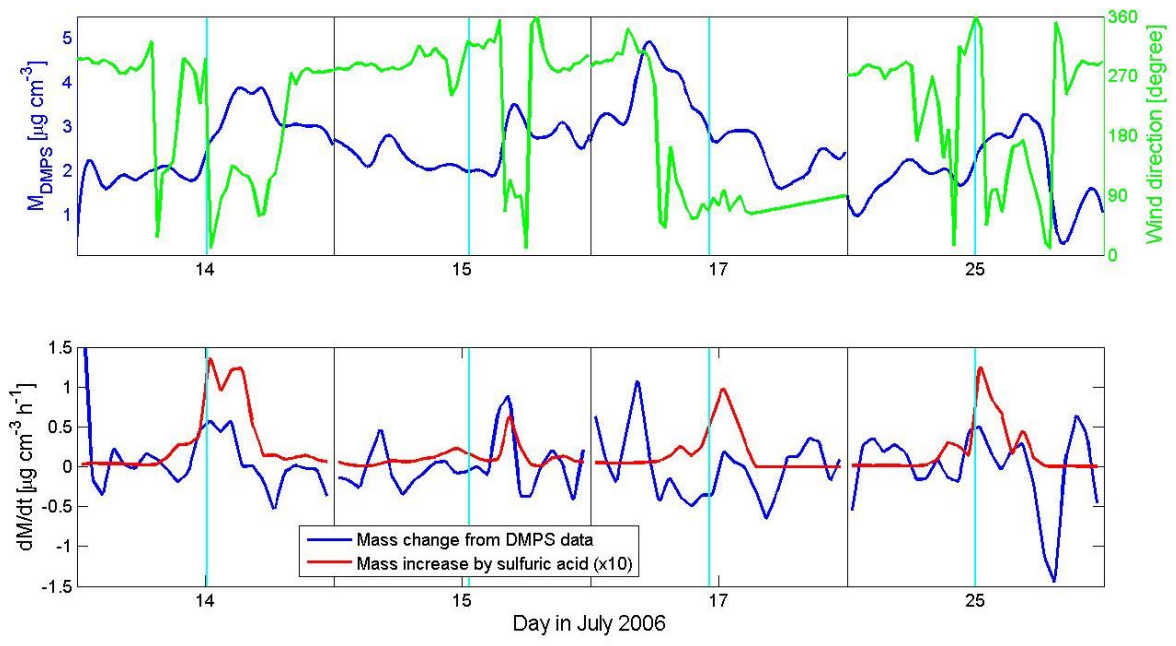

Fig. 11. Calculated mass and wind direction for 4 selected event days (upper plot); mass change and contribution by sulfuric acid (lower plot). The light blue vertical line indicates for each day the time when new particle formation was observed at the NWR.

change in wind-direction. On the 25 July, the mass and wind profiles behaved similarly to those on the 14 July, though the decrease in mass was significantly higher (by a factor of 6) on the 25th after the wind-direction changed back to the west. On the 17 July the mass and wind profiles do not behave similarly to the other three days. The highest mass loading occurs in the morning, before NPF and slightly after the wind-direction changed, and is higher than all other days (up to $5 \mu \mathrm{g} \mathrm{m}^{-3}$ ). Mass loss occurs throughout most of the day and evening, except for a short period of mass increase after NPF was observed. All selected event days show an increase in mass starting certain time before or after new particle formation was detected. This increase is correlated with a change of the wind-direction from west during night and early morning to southeast.

The lower plot of Fig. 11 presents the change of mass calculated from TDMPS data and the mass increase estimated by modelled uptake of sulphuric acid (Boy et al., 2005) (note the increase of mass by sulphuric acid uptake is multiplied by a factor of 10). On all days except the 15 July, sulphuric acid contributes between 5 and $30 \%$ to the mass increase after the occurrence of NPF. Similar contributions by sulphuric acid, 10-30\% were predicted using the 1-D model MALTE for the SMEAR II site at Hyytiälä (Boy et al., 2006) and $1-17 \%$ were reported for a rural area in Southern Germany (Held et al., 2004). On the 15 July, around the time 
NPF was observed particle mass increased slightly, reaching a maximum of $0.2 \mu \mathrm{g} \mathrm{m}^{-3} \mathrm{~h}^{-1}$. During this period sulphuric acid contributed more than $50 \%$ to the mass increase (calculated from the size distribution of all particles between 3 and $800 \mathrm{~nm}$ ). As mentioned previously (Sect. 3.2.1), sulphuric acid can be responsible for up to $50 \%$ of the growth of small clusters. It appears that at certain times, mostly around the appearance of newly formed particles, sulphuric acid could contribute to the mass increase with nearly the same value.

\section{Conclusions}

The present study focuses on new particle formation in the Front Range of the Colorado Rocky Mountains. We present an overall description of data collected during the campaign as well as a detailed analysis of the data for days in which particle bursts were observed. On most days we observed a characteristic wind pattern of cold air masses descending from the western slopes during night and early morning, changing to south-easterlies with warm air ascending after the onset of convection. NPF was always observed when warm and more polluted air masses (originating partly from the municipality of Denver) arrived at the station. However, most of these event days lacked the smallest particles (3$6 \mathrm{~nm}$ ), indicating that clusters or small particles around 1$2 \mathrm{~nm}$ formed in forested region of the Front Range approximately $10-15 \mathrm{~km}$ upwind of the measurement site. Temperature, incoming solar shortwave radiation and other investigated meteorological parameters did not show any correlation with the formation of new particles. Relative humidity was 10 to $20 \%$ lower on days when NPF occurred.

One interesting finding is that on clear event days the condensation sink values were higher compared to undefined and non-event days. This result suggests that, at this site, parameters other than the pre-existing aerosol loading are more important for particle nucleation and growth. Examples of such parameters include concentrations of sulphuric acid or mono- and sesquiterpenes, which were higher during most NPF events. Using TDMPS data without thermodenuder and the sulphuric acid concentration data we calculated the daily mass pattern and the mass change for the selected B-event days. All days showed an increase in mass starting at a certain time before or after new particle formation occurred. This increase was correlated with a change in wind-direction from the west during night and early morning to south-east during the day. During times when newly formed particles were observed sulphuric acid contributed between 5 to $30 \%$ and under certain circumstances up to $50 \%$ of the total particle mass change.

The growth of newly formed particles was calculated by a logarithmic fitting of the number size distributions with and without thermodenuder for the four selected Bevents days. The overall average calculated growth rates for particles between 1 and $15 \mathrm{~nm}$ were $3.96 \mathrm{~nm} \mathrm{~h}^{-1}$ with- out and $1.17 \mathrm{~nm} \mathrm{~h}^{-1}$ with thermal treatment. Once the particles reached a size of $15 \mathrm{~nm}$, a minimum growth rate was observed, followed by an increase to a mean value of $3.02 \mathrm{~nm} \mathrm{~h}^{-1}$ without TD and $1.3 \mathrm{~nm} \mathrm{~h}^{-1}$ with TD Another minimum was observed in the late evening when the sizes of the particles reached $30-35 \mathrm{~nm}$. The reasons for these growth patterns, observed on all four days, are still unclear but could be related to appearance and subsequent condensation of different organic molecules. Further investigations of the chemical compositions of particles with diameters $<30 \mathrm{~nm}$ are necessary to understand the nature of the growth processes in more detail. The ratio of the growth rates obtained form the thermodenuder compared to the ones without showed a clear relationship with the concentration of sesquiterpenes. This result - at least for the nucleation mode particles - suggests that chemical processes involving higher terpenes could be occurring in the particle, resulting in growth. By assuming that e.g. organic particle phase processes are important for the stabilisation of newly formed particles (concerning evaporation) sesquiterpenes could be a significant contributor to the new particle formation process.

The formation rate of particles with a diameter of $2 \mathrm{~nm}$ was calculated using measured aerosol size distributions and a parameterization published by Kerminen and Kulmala (2002). Further we estimated the formation rates based on three different nucleation theorems: "activation type nucleation", "kinetic type nucleation" and "activation of organic molecules". In comparing the particle formations rates based on the TDMPS system with values calculated from the three theories, some agreement was found for each nucleation mechanism on some time interval. Our results could not provide a definitive test whether the empirically determined $A$ - and $K$ coefficients from the kinetic and activation theories depend solely or to some extent on organic molecules.

Acknowledgements. The authors would like to thank the staff of the University of Colorado Mountain Research Station (W. Bowman, Director) for allowing us to use their facilities and for their assistance. We would also like to thank R. Monson and S. Burns of the Niwot Ridge AmeriFlux site for use of their data.

Edited by: K. Carslaw

\section{References}

Birmili, W., Stratmann, F., and Wiedensohler, A.: Design of a DMA-based size spectrometer for a large particle size range and stable operation, J. Aerosol Sci., 30(4), 549-554, 1999.

Birmili, W., Berresheim, H., Plass-Dülmer, C., Elste, T., Gilge, S., Wiedensohler, A., and Uhrner, U.: The Hohenpeissenberg aerosol formation experiment (HAFEX): a long-term study including size-resolved aerosol, $\mathrm{H} 2 \mathrm{SO} 4, \mathrm{OH}$, and monoterpenes measurements, Atmos. Chem. Phys., 3, 361-376, 2003, http://www.atmos-chem-phys.net/3/361/2003/. 
Bonn, B., Schuster, G., and Moortgat, G. K.: Influence of water vapor on the process of new particle formation during monoterpenes ozonolysis, J. Phys. Chem. A, 106(12), 2869-2881, 2002.

Bonn, B. and Moortgat, G. K.: Sesquiterpene ozonolysis: Origin of atmospheric new particle formation, Geophys. Res. Lett., 30, 1585, doi:10.1029/GL0017000, 2003.

Bonn, B., Korhonen, H., Petäjä, T, Boy, M., and Kulmala, M.: Understanding the formation of biogenic secondary organic aerosol from $\alpha$-pinene in smog chamber studies: role of organic peroxy radicals, Atmos. Chem. Phys. Discuss., 7, 3901-3939, 2007, http://www.atmos-chem-phys-discuss.net/7/3901/2007/.

Boy, M. and Kulmala, M.: Nucleation events in the continental boundary layer: Influence of physical and meteorological parameters, Atmos. Chem. Phys., 2, 1-16, 2002,

http://www.atmos-chem-phys.net/2/1/2002/.

Boy, M., Rannik, U., Lehtinen, K. E. J., Tarvainen, V., Hakola, H., and Kulmala, M.: Nucleation events in the continental PBL long term statistical analyses of aerosol relevant characteristics, J. Geophys. Res., 108(D21), 4667, doi:10.1029/2003JD003838, 2003.

Boy, M., Kulmala, M., Ruuskanen, T. M., Pihlatie, M., Reissell, A., Aalto, P. P., Keronen, P., Dal Maso, M., Hellen, H., Hakola, H., Jansson, R., Hanke, M., and Arnold, F.: Sulphuric acid closure and contribution to nucleation mode particle growth, Atmos. Chem. Phys., 5, 863-878, 2005,

http://www.atmos-chem-phys.net/5/863/2005/.

Boy, M., Hellmuth, O., Korhonen, H., Nillson, D., ReVelle, D., Turnipseed, A., Arnold, F., and Kulmala, M.: MALTE - Model to predict new aerosol formation in the lower troposphere, Atmos. Chem. Phys., 6, 4499-4517, 2006,

http://www.atmos-chem-phys.net/6/4499/2006/.

Brazel, A. and Brazel, P.: Summer diurnal wind patterns at Niwot Ridge, CO, Phys. Geog., 4, 53-61, 1983.

Dal Maso, M., Kulmala, M., Riipinen, I., Wagner, R., Hussein, T., Aalto, P. P., and Lehtinen, K. E. J.: Formation and growth of fresh atmospheric aerosols: eight years of aerosol size distribution datat from SMEAR II, Hyytiälä, Finland, Boreal Environ. Res., 10, 323-336, 2006.

De Gouw, J. A., Goldan, P. D., Warneke, C., Kuster, W. C., Roberts, J. M., Marchewka, M., Bertman, S. B., Pszenny, A. A. P., and Keene, W. C.: Validation of proton transfer reaction - mass spectrometry (PTR-MS) measurements of gas-phase organic compounds in the atmosphere during the New England Air Quality Study (NEAQS) in 2002, J. Geophys. Res., 108(D21), 4682, doi:10.1029/2003JD003863, 2003.

Fielder, V., Dal Maso, M., Boy, M., Aufmhoff, H., Hoffmann, J., Schuck, T., Birmili, W., Hanke, M., Uecker, J., Arnold, F., and Kulmala, M.: The contribution of sulphuric acid to atmospheric particle formation and growth: a comparison between boundary layers in Northern and Central Europe, Atmos. Chem. Phys., 5, 1773-1785, 2005, http://www.atmos-chem-phys.net/5/1773/2005/.

Fuchs, N. A. and Sutugin, A. G.: High-dispersed aerosols in Topics in Current Aerosol Research, edited by: Hidy, G. M. and Brock, J. R., Pergamon, Oxford, 2, 1-60, 1971.

Großmann, D: Die Gasphasenozonolyse von Alkenen in Gegenwart von Wasserdampf als Quelle f " ur Wasserstoffperoxid und organische Peroxide in der Atmosphäre, $\mathrm{PhD}$ thesis, Mainz University, Mainz, 1999.
Hansel, A., Jordan, A., Warneke, C., Holzinger, R., and Lindinger, W.: Improved detection limit of the proton-transfer reaction mass spectrometer: On-line monitoring of volatile organic compounds at mixing ratios of a few PPTV, Rapid Commun. Mass Sp., 12(13), 871-875, 1998.

Held, A., Nowak, A., Birmili, W., Wiedensohler, A., Forkel, R., and Klemm, O.: Observations of particle formation and growth in a mountainous forest region in Central Europe, J. Geophys. Res., 109, D23204, doi:10.1029/2004JD005346, 2004.

Huey, L. G., Dunlea, E. J., Lovejoy, E. R., Hanson, D. R., Norton, R. B., Fehsenfeld, F. C., and Howard, C. J.: A chemical ionization mass spectrometer for fast time response measurements of HNO3 in air, J. Geophys. Res., 103(D3), 3355-3360, 1998.

Hussein, T., Dal Maso, M., Petäjä, T., Koponen, I. K., Paatero, P., Aalto, P. P., Hämeri, K., and Kulmala, M.: Evaluation of an automatic algorithm for fitting the particle number size distributions, Boreal Environ. Res., 10, 37-355, 2005

Hyvönen, S., Junninen, H., Laakso, L., Dal Maso, M., Grönholm, T., Bonn, B., Keronen, P., Aalto, P., Hiltunen, V., Pohja, T., Launiainen, S., Hari, P., Mannila, H., and Kulmala, M.: A look at aerosol formation using data mining techniques, Atmos. Chem. Phys., 5, 3345-3356, 2005, http://www.atmos-chem-phys.net/5/3345/2005/.

Iinuma, Y., Mueller, C., Berndt, T., Böge, O., Claeys, M., and Hrmann, H.: Evidence for the existence of organosulfates from a-pinene ozonolysis in ambient secondary organic aerosol, Environ. Sci. Technol., 41, 6678-6683, 2007.

Kallberer, M., Sax, M., and Asamburova, V.: Molecular size evolution of oligomers in organic aerosols collected in urban atmospheres and generated in a smog chamber, Environ. Sci. Technol., 40, 5917-5922, 2006.

Kalberer, M., Paulsen, D., Sax, M., Steinbacher, M., Dommen, J., Prevot, A. S. H., Fisseha, R., Weingartner, E., Frankevich, V., Zenobi, R., and Baltensperger, U.: Identification of polymers as major components of atmospheric organic aerosols, Science, 303, 1659-1662, 2004.

Kerminen, V.-M. and Kulmala, M.: Analytical formulae connecting the "real" and the "apparent" nucleation rate and the nuclei number concentration for atmospheric nucleation events, J. Aerosol Sci., 33, 609-622, 2002.

Korhonen, H., Lehtinen, K. E. J., and Kulmala, M.: Multicomponent aerosol dynamics model UHMA: model development and validation, Atmos. Chem. Phys., 4, 757-771, 2004, http://www.atmos-chem-phys.net/4/757/2004/.

Kulmala, M., Dal Maso, M., Mäkelä, J. M., Pirjola, L., Väkevä, M., Aalto, P., Miikkulainen, P., Hämeri, K., and O’Dowd, C.: On the formation, growth and composition of nucleation mode particles, Tellus B, 53, 479-490, 2001.

Kulmala, M.,Vehkamäki, H., Petäjä, T., Dal Maso, M., Lauri, A., Kerminen, V.-M., Birmili, W., and McMurry, P. H.: Formation and growth rates of ultrafine atmospheric particles: A review of observations, J. Aerosol Sci., 35, 143-176, 2004.

Kulmala, M., Lehtinen, K. E. J., and Laaksonen, A.: Cluster activation theory as an explanation of the linear dependence between formation rate of $3 \mathrm{~nm}$ particles and sulphuric acid concentration, Atmos. Chem. Phys., 6, 787-793, 2006,

Kulmala, M., Riipinen, I., Sipilä, M., Manninen, H. E., Petäjä, T., Junninen, H., Dal Maso, M., Mordas, G., Mirme, A., Vana, M., Hirsikko, A., Laakso, L., Harrison, R. M., Hanson, I., Le- 
ung, C., Lehtinen, K. E. J., and Kerminen, V.-M.: Toward direct measurement of atmospheric nucleation, Sciencexpress, 318, 89, doi:10.1126science.1144124, 2007.

Lehtinen, K. E. J. and Kulmala, M.: A model for particle formation and growth in the atmosphere with molecular resolution in size, Atmos. Chem. Phys., 3, 251-257, 2003,

Leibrock, E. and Huey, L. G.: Ion chemistry for the detection of isoprene and other volatile organic compounds in ambient air, Geophys. Res. Lett. 27, 12, 1719-1722, 2000.

Lindinger, W., Jordan, A., and Hansel, A.: Proton-transfer-reaction mass spectroscopy (PTR-MS): on-line monitoring of volatile organic compounds at pptv levels, Chem. Soc. Rev., 27, 347-534, 1998.

Lindinger, W., Fall, R., and Karl, T.: Environmental, food and medical applications of Proton-Trnasfer-Reaction Mass Spectrometry (PTR-MS), in: Advances in Gas-Phase Ion Chemistry, edited by: Adams, N. G., Elsevier Science B. V., 1-35, 2001.

McMurry, P. H. and Friedlander, S. K.: New particle formation in the presence of an aerosol, Atmos. Environ., 13, 1635-1651, 1979.

Parrish, D. D., Hahn, C. H., Fahey, D. W., Williams, E. J., Bollinger, M. J., Hubler, G., Buhr, M. P., Murphy, P. C., Trainer, M., Hsie, E. Y., Liu, S. C., and Fehsenfeld, F. C.: Systematic variations in the concentrations of NOx (NO Plus NO2) at Niwot Ridge, Colorado, J. Geophys. Res., 95, 1817-1836, 1990.

Riipinen, I., Sihto, S.-L., Kulmala, M., Arnold, F., Dal Maso, M., Birmili, W., Teinilä, K., Kerminen, V.-M., Laaksonen, A., and Lehtinen, K. E. J.: Connections between atmospheric sulphuric acid and new particle formation during QUEST II-IV campaigns in Heidelberg and Hyytiälä, Atmos. Chem. Phys., 7, 1899-1914, 2007 ,

http://www.atmos-chem-phys.net/7/1899/2007/.
Shu, Y. and Atkinson, R.: Rate constants for the gas-phase reactions of $\mathrm{O}_{3}$ with a series of terpenes and $\mathrm{OH}$ radical formation from the $\mathrm{O}_{3}$ reactions with sesquiterpenes at $2962 \mathrm{~K}$, Int. J. Chem. Kin., 26, 1193-1205, 1994.

Sihto, S.-L., Kulmala, M., Kerminen, V.-M., Dal Maso, M., Petäjä, T., Riipinen, I., Korhonen, H., Arnold, F., Janson, R., Boy, M., Laaksonen, A., and Lehtinen, K. E. J.: Atmospheric sulphuric acid and aerosol formation: implications from atmospheric measurements for nucleation and early growth mechanisms, Atmos. Chem. Phys., 6, 4079-4091, 2006, http://www.atmos-chem-phys.net/6/4079/2006/.

Surrat, J. D., Kroll, J. H., Kleindienst, T. E., Edney, E. O., Clayes, M., Sorooshinan, A., Ng, N. L., Offenberg, J. H., Lewandowski, M., Jaoui, M., Flagan, R. C., and Seinfeld, J. H.: Evidence for ogransolufates in secondary organic aerosol, Environ. Sci. Technol., 40, 517-527, 2007.

Turnipseed, A. A., Blanken, P. D., Anderson, D. E., and Monson, R. $\mathrm{K}$.: Energy budget above a subalpine forest in complex terrain, Agr. Forest Meteorol., 110, 177-201, 2002.

Wehner, B., Philippin, S., and Wiedensohler, A.: Design and calibration of a thermodenuder with an improved heating unit to measure the size-dependent volatile fraction of aerosol particles, J. Aerosol. Sci., 33, 1087-1093, 2002.

Wu, Z., Hu, M., Liu, S., Wehner, B., Bauer, S., Maßling, A., Wiedensohler, A., Petäjä, T., Dal Maso, M., and Kulmala, M.: New particle formation in Beijing, China: Statistical analysis of a 1-year data set, J. Geophys. Res., 112, D09209, doi:10.1029/2006JD007406, 2007. 